\title{
Isolation and molecular characterization of some copper biosorped strains
}

\author{
S. Zaki; *S. Farag \\ Department of Environmental Biotechnology, Genetic Engineering and Biotechnology Research Institute, \\ Mubarak City for Scientific Research and Technology Applications, Alexandria, Egypt \\ Received 15 December 2009; revised 23 April 2010; accepted 20 May 2010; availaEQHonline 1 June 2010
}

\begin{abstract}
The biosorption of copper (II) from aqueous solution using different bacterial strains was studied. Copper-biosorbing bacteria were isolated from tannery effluent collected from Borg Al-Arab, Alexandria, Egypt. These isolates displayed different degrees of copper biosorption under aerobic conditions. Based on 16S rDNA gene sequence analysis, three of them (S2, S5 and S7) were identified as Chryseobacterium sp., Enterobacter sp. and Stenotrophomonas sp., respectively. Initial copper (II) ion concentrations from 25-250 mg/L at constant temperature $30{ }^{\circ} \mathrm{C}$ were studied. The residual copper (II) concentration and its toxicity effect in solution were determined using atomic absorption spectrophotometer and bioluminescent bioreporter. The bioluminescence inhibition of strain (S5) reached to $91.4 \%$ as compared with the strain (S7) reached to $83.3 \%$ at $225 \mathrm{mg} / \mathrm{L}$ of copper ion where the maximum biosorption efficiency for S5 and S7 were $71 \%$ and $70.1 \%$ correspondingly using atomic absorption. The bioluminescent bioreporter was proved to be fast and accurate technique for measurement the toxicity effect of residual copper (II) in solution.
\end{abstract}

Keywords: Bacterial strains; Bioluminescent; Biosorption; Restriction fragment length polymorphism

\section{INTRODUCTION}

Heavy metals are groups of pollutants, which are not biodegradable and tend to accumulate in living organisms (Kobya et al., 2005). The concentrations of these metals need to be reduced to meet ever-changing legislative standards. According to the World Health Organization (WHO, 2010), the metals of most immediate concern include cadmium, chromium, cobalt, copper, lead, nickel, mercury and zinc. The presence of such metals in aquatic environments cause severe damage to aquatic life and killing microorganisms during biological water purification process (Vinodhini and Narayan, 2008). Moreover, these metals have exacting consequences on humans such as brain damage, reproductive failures, nervous system failures and tumor formation (Hamman, 2004; Mahvi, 2008). Copper, one of the most widely used heavy metals, is mainly employed in electrical and electroplating industries and in larger amounts is extremely toxic to living organisms. The presence of copper (II) ions, cause serious toxicological concerns, it is usually known to deposit in brain, skin, liver, pancreas and myocardium (Davis et al., 2000).

*Corresponding Author Email: sohafarag88@yahoo.com Tel.: +203 4593418; Fax: +203 4593423
Conventional techniques for removing dissolved heavy metals include chemical precipitation, carbon adsorption, electrolytic recovery, ion-exchange, chelation and solvent extraction or liquid membrane separation (Vasudevan et al., 2003; Lodeiro et al., 2005; Liu et al., 2006; Sharma et al., 2006; Samarghandi et al., 2007; Malakootian et al., 2009) all exhibit several disadvantages, such as high cost, incomplete removal, low selectivity, high energy consumption (Panjeshahi and Ataei, 2008) and generation of toxic slurries that are difficult to be eliminated (Celaya et al., 2000; Okafor and Opuene, 2007). Therefore, much attention has been paid to the removal of metal ions by microorganisms due to its potential applications in environmental protection and recovery of toxic or strategic heavy metals (Tsezos, 1985; Forest and Roux,1992; Chang and Hong, 1994; Chang et al., 1997; Babel and Opiso, 2007; Zvinowanda et al., 2009; Andreazza et al., 2010). Certain types of microbial biomass are considered to retain relatively high quantities of metals by means of passive process known as biosorption. Biosorption utilizes various natural materials, including fungi, yeast and bacteria that have been studied to sequester metal ions from aqueous 
solution and it represents a cheap alternative to conventional processes due to the use of a low cost sorbent material (Nameni et al., 2008; Abdel-Ghani et al., 2009; Silva et al., 2009; Yahaya et al., 2009). Biosorption is either metabolism independent, such as physical or chemical sorption onto the microbial cell walls, or metabolism associated, such as transport, internal compartmentalization and extracellular precipitation by metabolites. In addition, an important aspect of biosorption is that it can be carried out either with metabolically active or inactive cells (Kurek et al., 1982; Brierley, 1990; Volesky, 1994; Chen et al., 2000).

Several toxicity bioassays have been described and different methods using microorganisms have been used to assess the acute toxicity of industrial wastewaters. Among these bioassays are bioluminescence tests (Kahru et al., 2000). This test is based on the inhibition of the bioluminescence of luminescent bacteria (lights off). The lights off assays is an extension of the widely accepted microbial toxicity bioassays, which is based on the measurement of a decrease in light emission as a function of sample concentration by the wild type luminescent bacteria Vibrio fischeri following a short time exposure to the sample (Quershi et al., 1998).

In the present study, the biosorption of $\mathrm{Cu}$ (II) from aqueous solution using different bacterial strains was studied. The RFLP using different enzymes was carried out, also the $16 \mathrm{~S}$ rDNAs were amplified and partially sequenced, compared with sequences deposited in databases. The biosorption efficiency of different copper ion concentrations from loaded biosorbent was assessed using atomic absorption spectrophotometer, and bioluminescent biosensor technique.

This work was performed in Mubarak City for Scientific Research and Technology Applications, Alexandria, Egypt from 2008 to 2009

\section{MATERIAL AND METHODS}

Isolation of copper-resistant bacteria

Copper-resistant bacteria were isolated from tannery effluent obtained from a company at New Burg El-Arab City, Alexandria, Egypt. For the isolation and enumeration of bacteria, samples were serially diluted and plated on Luria-Bertani (LB) agar (tryptone: $10 \mathrm{~g} /$ $\mathrm{L}$; yeast extract: $5 \mathrm{~g} / \mathrm{L}$; $\mathrm{NaCl}: 10 \mathrm{~g} / \mathrm{L}$; glucose: $0.1 \mathrm{~g} / \mathrm{L}$ ) adjusted at natural $\mathrm{pH}$ value of the medium from 6.5 to 7.0 without any additions. The molten medium was amended with $\mathrm{Cu}$ (II) as $\mathrm{CuSO}_{4}$ to final concentration
$50 \mathrm{mg} / \mathrm{L}$ using sterile filtered $\mathrm{Cu}$ (II) stock solutions. Plates were incubated at $30{ }^{\circ} \mathrm{C}$ in the dark and were read after 2 days. Seven copper-resistant isolates representing different colony morphologies were purified on LB agar containing $50 \mathrm{mg} / \mathrm{L}$ of $\mathrm{Cu}$ (II).

\section{Evaluation of Cu (II)-resistance}

The minimum inhibitory concentration (MIC) of the seven $\mathrm{Cu}(\mathrm{II})$-resistant isolates were determined by broth dilution method (Calomoris et al., 1984) in LB medium with $\mathrm{Cu}$ (II) concentrations ranged from 50 to $250 \mathrm{mg} / \mathrm{L}$. The minimum concentration of metal in the medium inhibiting complete growth was taken as the MIC. Out of these results three isolates (S2, S5 and S7) were selected for further analysis.

\section{Copper biosorption by the isolates}

Copper-resistant isolates (S2, S5 and S7) were inoculated into LB broth containing different concentrations of $\mathrm{Cu}$ (II) (from 25 to $250 \mathrm{mg} / \mathrm{L}$ ) and incubated for $72 \mathrm{~h}$ at $30{ }^{\circ} \mathrm{C}$ with orbital shaking (200 $\mathrm{rpm})$. The inoculum was $2 \%$ of total volume of media. Bacterial cell density (diluted 10-fold with water) of the liquid cultures was determined by measuring optical density at $600 \mathrm{~nm}$ by using UV/Vis spectrophotometer (DU.530 Beckman) (Andreazza et al., 2010; Sultan and Hasnain, 2007). Residual of biosorped Cu (II) was determined from extracted solution by using a PerkinElmer Analyst 300 atomic absorption spectrophotometer (AAS). All the above experiments were performed in triplicates and the mean value was determined.

\section{Residual of Cu (II) toxicity assay}

The toxicity assay was performed using a bioluminescent bioreporter Acinetobacter strain DF4/ PUTK2 that had been genetically modified by conjugation (Abd-El-Haleem et al., 2006) to contain the PUTK2 plasmid (Burlage et al., 1990), with the Tn4431 lux transposon downstream of a putative plasmid maintenance promoter to produce continual visible bioluminescence light. Bioluminescence was measured at 5 min regular time intervals from zero to 480 min by a luminometer (LumiStar, Galaxy, BMG, Germany). To perform the assay, a culture of the bioreporter strain DF4/PUTK2 was grown in LB medium on an orbital shaker at $200 \mathrm{rpm}$ at $30{ }^{\circ} \mathrm{C}$ for $16 \mathrm{~h}$. Subsequently, the cells were diluted 1:10 in LB medium and incubated on an orbital shaker at $30^{\circ} \mathrm{C}$ to achieve 
an optical density of 0.6 measured with a spectrophotometer at $600 \mathrm{~nm}$ (Sultan and Hasnain, 2007; Andreazza et al., 2010). After two washes in a sterile LB medium, the pellet was resuspended in $1 \mathrm{~mL}$ sterile LB. Subsequently, aliquots $100 \mu \mathrm{L}$ of each sample mixed with $100 \mu \mathrm{L}$ of a DF4/PUTK2 cell suspension were transferred to 96-well microtiter plates (Nunc) to produce 4 replications of each sample. Along with each treatment two controls were incorporated into each plate, the first contained $100 \mu \mathrm{L}$ from the bioreporter DF4/PUTK2 mixed with $100 \mu$ MilliQ water (no toxicity control), while the second control contained the bioreporter mixed with the original samples (non diluted toxic substances). Wells were then covered with transparent plate sealer and placed in the luminometer for luminescence detection at room temperature.

\section{PCR-RFLP fingerprints of the 16S rDNA gene}

The RFLP was carried out according to (Abd-ElHaleem et al., 2003). EcoR1, BamH1, HaeIII, HindIII, HincII, and HinfI are the restriction enzymes used for RFLP of the $16 S$ rDNA genes. A volume of $15 \mu \mathrm{L}$ of amplified 16S rDNA was separately digested for $3 \mathrm{~h}$ at $37^{\circ} \mathrm{C}$ with $2 \mathrm{U}$ of each restriction enzyme(GIBCOB.R.L). The fragments were separated by electrophoresis on $2 \%$ agarose gels (FMC, Rockland, USA) containing Ethedium bromide at $0.1 \mu \mathrm{g} / \mathrm{mL}$. Gels were run at $100 \mathrm{~V}$ for $3 \mathrm{~h}$ in $1 \mathrm{x}$ TBE buffer and then visualized and photographed in the multiImage light cabinet (Alpha Imger ${ }^{\mathrm{TM}} 1220$ ). $100 \mathrm{bp}$ and $1 \mathrm{~kb}$ ladder mix (Sigma, St. Louis, MO) were used as molecular weight marker

\section{Molecular identification}

Amplification of 16S rDNA with eubacterial universal primers $27 \mathrm{~F}$ and $1492 \mathrm{R}$ was done (Lane, 1991). Genomic DNAs and/or PCRs were performed using EZ-10 Spin Column DNA purification kit according to the manufacturer's instructions (BIO BASIC INC.). Sequencing was performed using ABI PRISM dye terminator cycle sequencing kit with AmpliTaq DNA polymerase and an Applied Biosystems 373 DNA sequencer (Perkin-Elmer, Foster City, California).

The sequences were analyzed using the CHECK CHIMERA and the SIMILARITY RANK programs of the Ribosomal Database Project (Altschul et al.,1990) also analyzed using the BLAST program (National Centre for Biotechnology Information) to determine the closest available database sequences. Selected rDNA sequences were aligned using the Clustal W program (Hall, 1999). Published sequences were obtained from
GenBank. A phylogenetic tree was constructed using Clustal W by distance matrix analysis and the neighbourjoining method (Saitou and Nei, 1987). Phylogenetic trees were displayed using TREEVIEW (Page, 1996).

\section{RESULTS AND DISCUSSION}

Isolation and evaluation

In search for copper-resistant microorganisms, a total of seven Cu-resistant bacteria were isolated from tannery effluent obtained from a company in Borg Al-Arab, Alex. Egypt. The effect of $\mathrm{Cu}$ (II) concentrations (MIC test) ranging from 50 to $250 \mathrm{mg} / \mathrm{L}$ on the growth of the isolates was evaluated according to Yahaya et al., (2009) who used different $\mathrm{Cu}$ (II) concentration varying from 50 to $300 \mathrm{mg} / \mathrm{L}$. From the results presented in Fig. 1, the most significant growth decreased after addition of $200 \mathrm{mg} / \mathrm{L}$ of $\mathrm{Cu}$ (II) was observed with isolates S1, S3, S4, S6 and S7. However, the growth of isolate S7 was more comparing to the other isolates at different copper concentrations. Isolates S2 and S5 were growing well when exposed to the highest copper concentration, till $250 \mathrm{mg} / \mathrm{L}$. However, the MIC of strains S1, S3, S4, S6 and S7 was $200 \mathrm{mg} / \mathrm{L}$, while it was $250 \mathrm{mg} / \mathrm{L}$ with strains S2 and S5, respectively more than $250 \mathrm{mg} / \mathrm{L}$ of Cu was toxic for the bacterial strains (data not shown). The detoxification efficiency of the seven respective isolates follows the sequence: $\mathrm{S} 1>\mathrm{S} 3>\mathrm{S} 4>\mathrm{S} 6>\mathrm{S} 7>\mathrm{S} 2>\mathrm{S} 5$. However, three isolates S2, S5 and S7 were the most resistant strains and selected for further analysis. Previously, Shakibaie et al. (2008) reported 9 strains able to resist $\mathrm{Cu}$ up to $0.5 \mathrm{mM}$ according to their MIC.

\section{PCR-RFLP fingerprints of the 16S rDNA gene}

In order to evaluate the applicability of restriction enzyme analysis of the examined isolates and to select the restriction enzyme that gives the highest level of discrimination, PCR-RFLP analysis was performed using each of the following restriction endonucleases: BamH1, EcoR1, HaeIII, HindIII, HincII, Hinf1. No and/ or poor digestion was observed with EcoRI, HindIII, BamHI and HincII. However, the most differentiating banding pattern was showed with enzymes HaeIII and HinfI (Fig. 2). Previously, Abd-El-Haleem et al. (2003), reported that HinfI is the most suitable enzyme for RFLP analysis for the $16 \mathrm{~S}$ rDNA amplicons.

\section{Identification and phylogenetic analysis}

The 16S rDNA genes of the isolates were partially sequenced following PCR amplification and compared with sequences deposited in databases. Totally $\sim 700$ 


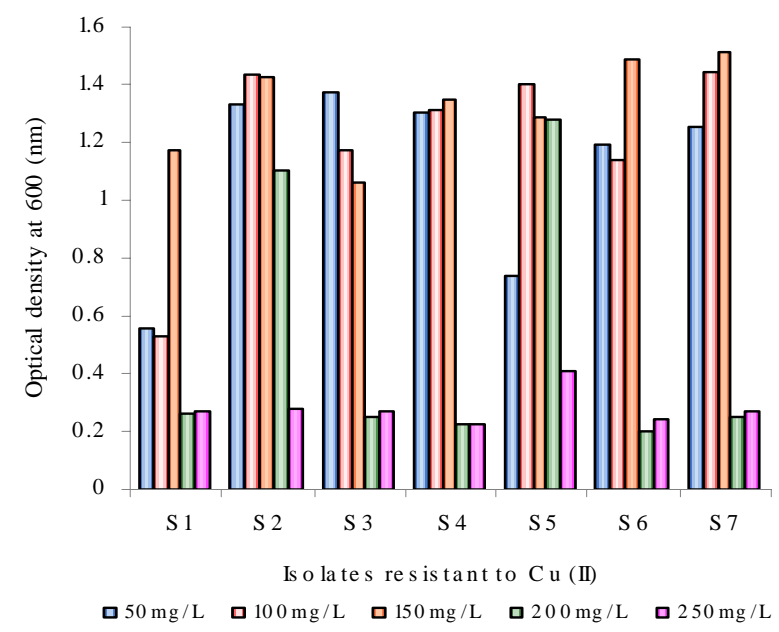

Fig. 1: Effect of different Cu (II) concentrations on the growth of seven selected isolates

bp of the 16S rDNA of isolates S2, S5 and S7 was determined. The phylogenetic tree (Fig. 3) showed that isolate S2 was closely related to Chryseobacterium sp. exhibiting similarity values greater than $94 \%$. Isolate S5 was belonging to Enterobacter sp. with similarity value $>98 \%$. However, isolate S7 was related to Stenotrophomonas $s p$. with similarity value $>87 \%$. The nucleotide sequence data reported in this study have been deposited in the NCBI nucleotide sequence database (Gen Bank) under the accession number of FJ827754, FJ827755 and FJ827756, respectively. It was previously emphasized that some strains related to the genus Enterobacter and Stenotrophomonas have been described for their ability to biosorp copper ion (Alluri et al., 2007; Parungao et al., 2007). Historically, the 16S rDNA gene has been chosen by many workers for phylogenetic studies because of its relatively small size which facilitates sequence analysis. As a result, several thousands of 16S rDNA sequences are available (AbdEl-Haleem et al., 2002a and b; 2003).

Determination of accumulation efficiency of the isolates

The ability of cupper-resistant bacterial strains (S2, S5 and S7) for reduction of different concentrations of $\mathrm{Cu}$ (II) ranged from 25 - $250 \mathrm{mg} / \mathrm{L}$ were determined spectrophotometrically readings after 72hrs at 30ÚC in LB media. At different concentrations of Cu (II), Fig. 4 and Fig. 5 show cellular growth and biosorption efficiency (\%) of Chryseobacterium sp. strain S2, Enterobacter sp. strain S5, and Stenotrophomonas sp. strain S7, respectively. A progressive decrease was showed in growth by increasing $\mathrm{Cu}(\mathrm{II})$ concentrations (Fig. 4). The result obtained pointed out that the exact MIC for strains S2, S5 and S7 was 225, 250 and $200 \mathrm{mg} /$ $\mathrm{L}$, respectively. These selected strains according to their MIC similarly to Vullo et al. (2008) who chosen five of eleven strains due to their highest MIC for heavy metal and highest biomass yield in constant incubation time.

Fig. 5 represents the percentage of copper biosorption efficiency using atomic absorption spectrophotometer. The \% of biosorption efficiency was increased as the initial copper ion concentration increased. The result implies that the gradual increase in the efficiency of the strain shows nearness to saturation of the available binding sites. These results agree with the result of Adesola Babarinde et al. (2007). The maximum biosorption efficiency of $225 \mathrm{mg} / \mathrm{L} \mathrm{Cu}$ by isolates S2, S5 and S7 was $48 \%, 71 \%$ and $70.1 \%$, respectively. It is established that biosorption of metal ions has been reported to be biphasic (Liu et al., 2006). The initial fast phase occurs due to surface adsorption on the biomass. The subsequent slow phase occurs due to diffusion of the metal ions into the inner part of the biomass. In the present study (Fig. 5), it was observed that the metal biosorption rate was high at the beginning of the process but plateau values were obtained after constant concentration, similar to what was reported by Liu and coworkers (Liu et al., 2006). Also Andreazza et al. (2010) reported that the rate of bacterial growth, $\mathrm{Cu}$ (II) removal and $\mathrm{Cu}$ (II) bioreduction were directly related to $\mathrm{Cu}$ (II) concentration. Increasing the concentration of $\mathrm{Cu}$ (II) lowered growth due to its toxic effects. However, increasing concentration increased $\mathrm{Cu}$ (II) reduction and removal. A similar relationship between concentration and bioremoval was reported for a heavy metal by Okeke et al. (2008) and Okeke (2008). At the highest copper concentration, isolate NA strongly reduced and removed copper indicating high capacity for $\mathrm{Cu}$ (II) biotransformation.

\section{Bioluminescence assay}

The environmental protection against the harmful industrial wastes requires fast and reliable techniques to assess the wastes in order to apply the necessary bioremediation measures in the appropriate time (AbdEl-Haleem et al., 2006; Zaki et al., 2008). The residual Cu (II) concentrations was evaluated using bioluminescent biosensor, this techniques are gaining wide acceptance in environmental studies. The bioluminescence assay 
Int. J. Environ. Sci. Tech., 7 (3), 553-560, Summer 2010

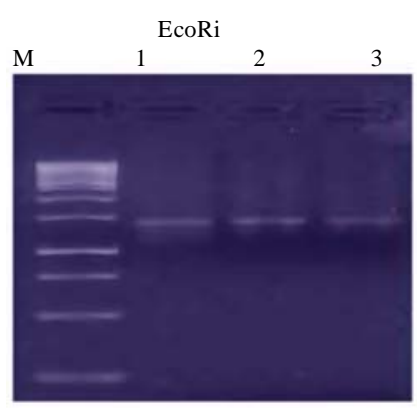

HincII

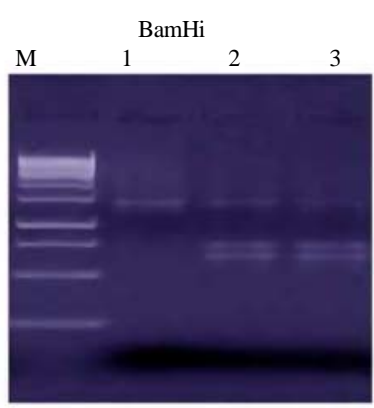

HindIII

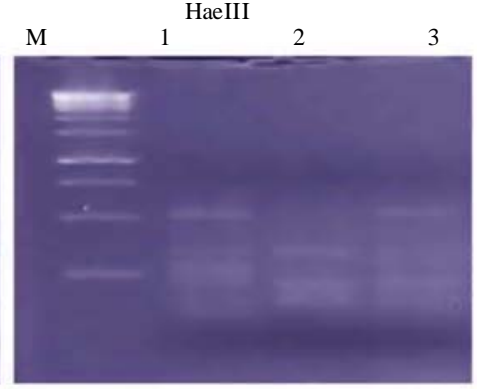

HinfI
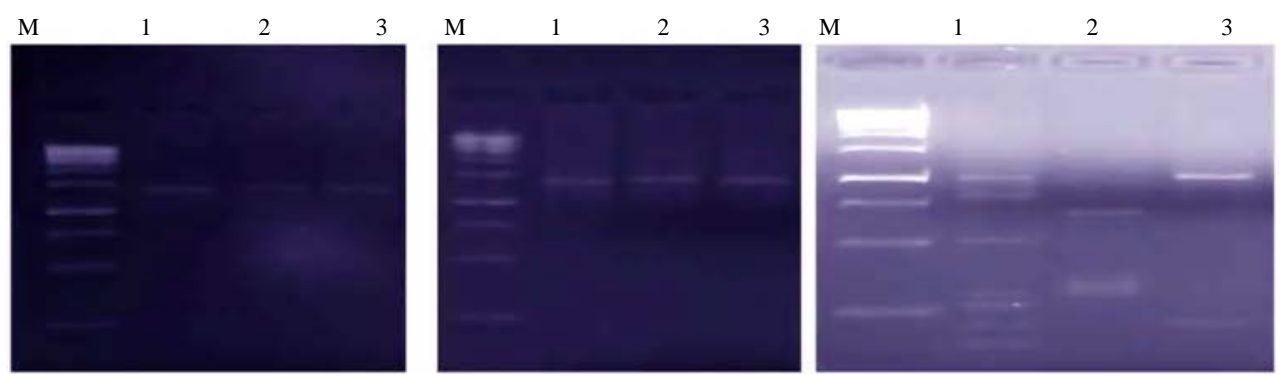

Fig. 2: Gel electrophoresis RFLP of $16 \mathrm{~S}$ rDNA

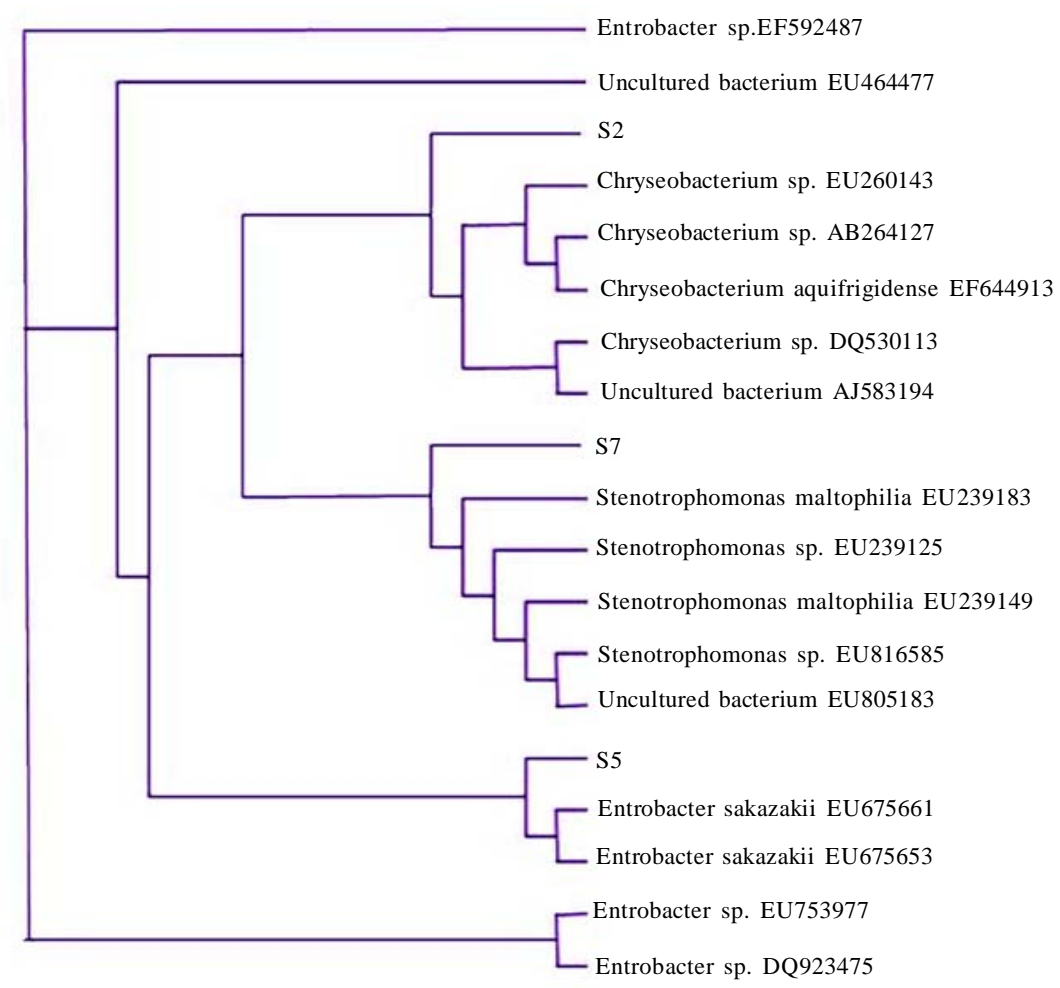

Fig. 3: Phylogenetic tree showing the relationships among selected isolates 
can in short time (45 min only) show the response of the bioreporter strain DF4/PUTK2 to the toxic effect of certain pollutants. Similar bioassay methods were also based on microbial bioassays and biosensors were presented elsewhere (Abd-El-Haleem et al., 2006; Zaki et al., 2008). In present study, from the results obtained in Fig. 5 represent that strains S5 and S7 were the most potent for $\mathrm{Cu}$ biosorption so we selected them for bioluminescence assay. Fig. 6 shows that the bioluminescence of the bioreporter strain DF4/PUTK2 was decreased with increasing the concentrations of $\mathrm{Cu}$ from $25-250 \mathrm{mg} / \mathrm{L}$. The results show that the bioluminescence inhibition of strain (S5) reached to 91.4 $\%$ as compared with the strain (S7) reached to $83.3 \%$ at $225 \mathrm{mg} / \mathrm{L}$ of $\mathrm{Cu}$ ion. Finally, the data presented in this research indicated that with the use of metal resistant bacteria, the bioremediation of heavy metals from effluents of the factories can considerably be enhanced and the disposal problems of the waste with little expense is improved.

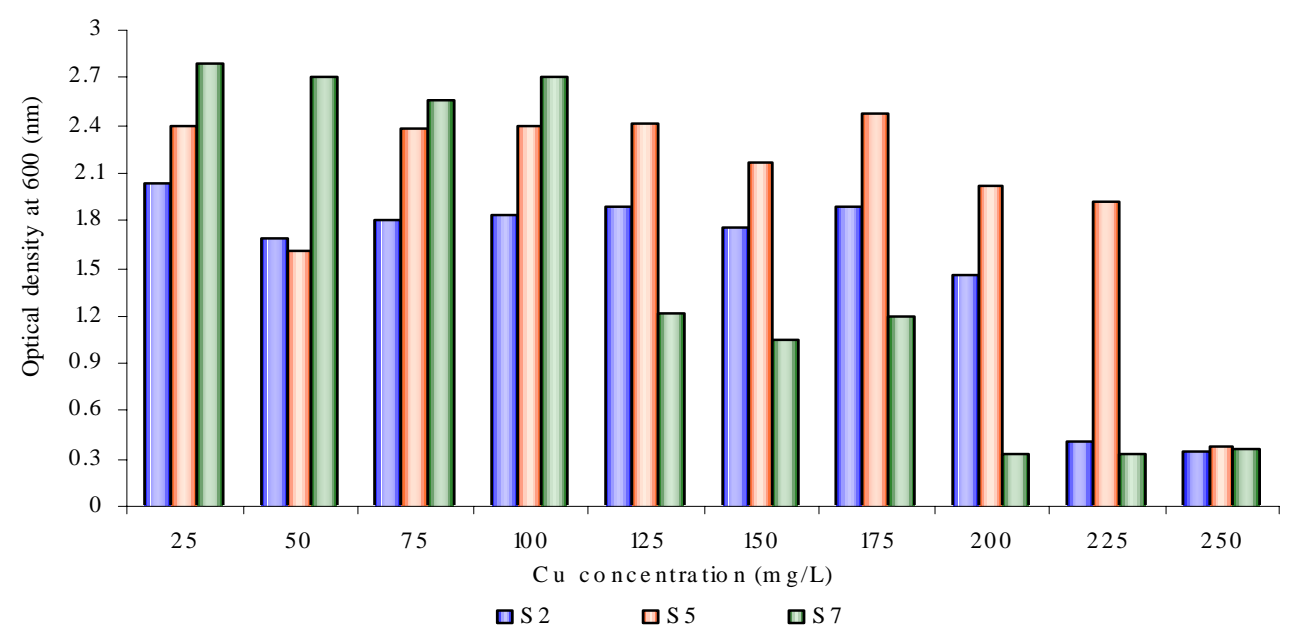

Fig. 4: Effect of various concentrations of $\mathrm{Cu}(\mathrm{II})(\mathrm{mg} / \mathrm{L})$ on the growth of strains S2, S5 and S7

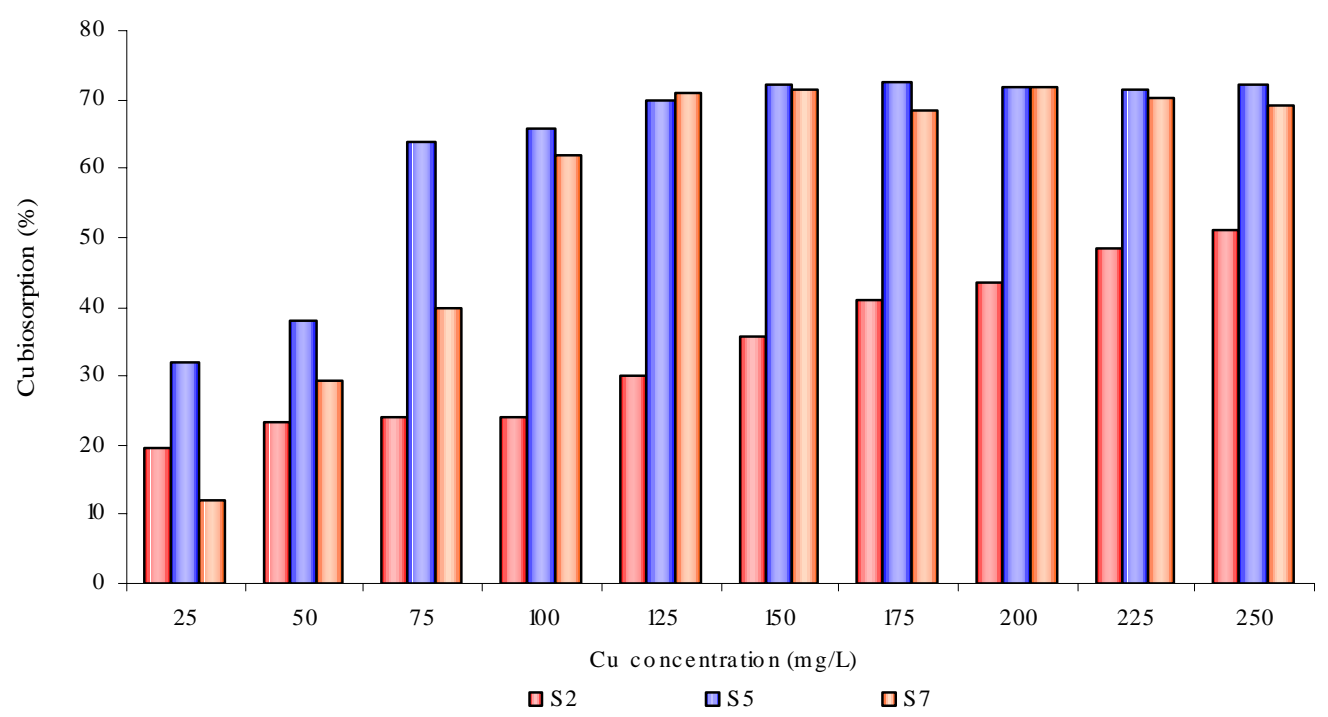

Fig. 5: Influence of initial Cu (II) concentrations on the rate of copper biosorption by S2, S5 and S7 


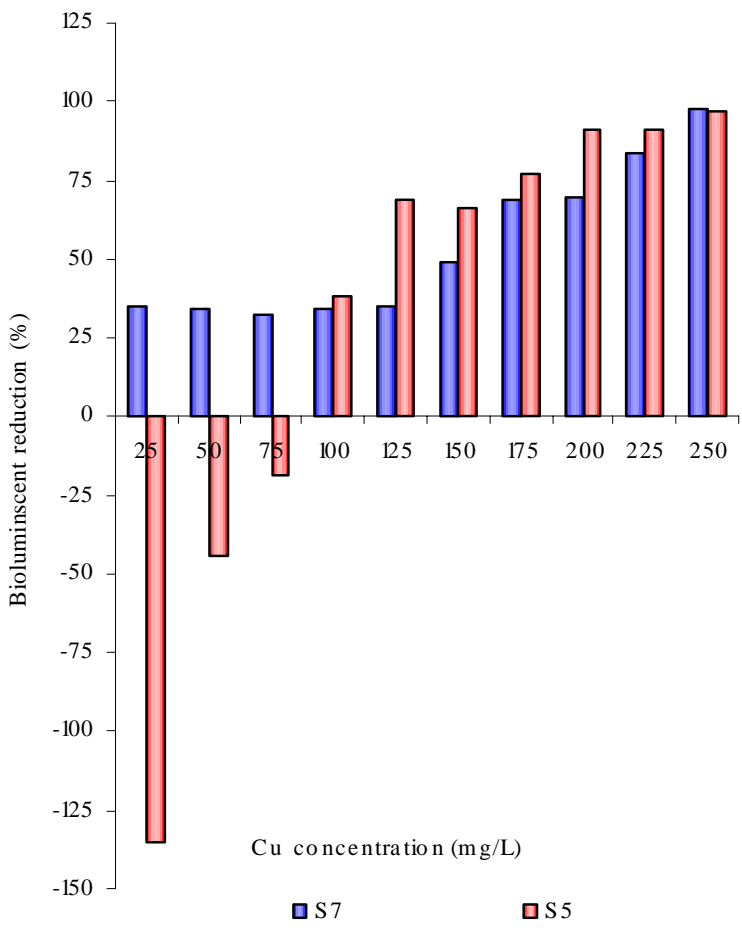

Fig. 6: Bioluminescent reduction efficiency

\section{REFERENCES}

Abdel-Ghani, N. T.; Hegazy, A. K.; El-Chaghaby, G. A., (2009). Typha domingensis leaf powder for decontamination of aluminium, iron, zinc and lead: Biosorption kinetics and equilibrium modeling. Int. J. Environ. Sci. Tech., 6 (2), 243248 (6 pages).

Abd-El-Haleem, D.; Moawad, H.; Zaki, E. A.; Zaki S., (2002b). Molecular characterization of phenol-degrading bacteria isolated from different egyptian ecosystems. Microb. Ecol., 43 (1), 217-224 (8 pages).

Abd-El-Haleem, D.; Zaki, S.; Abulhamid, A.; Elbery, H.; Abu Elreesh, G., (2006). Acinetobacter bioreporter assessing heavy metals toxicity. J. Basic Microbiol., 46 (5), 339-347 (9 pages).

Abd-El-Haleem, D.; Layton, A.; Sayler, G., (2002a). Long-PCR amplified rDNA apply for PCR-RFLP and REP-PCR based approaches to recognize closely related microbial species. J. Microbio. Meth., 49 (3), 315-318 (4 pages).

Abd-El-Haleem, D.; Kheiralla, Z.; Zaki S.; Rushdy A.; Abd-ElRahiem, W., (2003). Multiplex-PCR and PCR-RFLP assays to monitor water quality against pathogenic bacteria. J. Environ. Monit., 5 (4), 865-870 (6 pages).

Adesola Babarinde, N. A.; Oyesiku, O. O.; Dairo O.F., (2007). Isotherm and thermodynamic studies of the biosorption of copper (II) ions by Erythrodontium barteri. J. Physic. Sci., 2 (11), 300-304 (5 pages).

Alluri, H. K.; Ronda, S. R.; Settalluri, V. S.; Bondili, J. S.; Suryanarayana, V.; Venkateshwar, P., (2007). Biosorption: an eco-friendly alternative for heavy metalremoval. Afr. J. Biotechnol., 6 (25), 2924-2931 (8 pages).

Altschul, S. F.; Gish, W.; Miller, W.; Myers, E. W.; Lipman, D.
J., (1990). Basic local alignment search tool. J. Mol. Biol., 215 (3), 403-410 (8 pages)

Andreazza, R.; Pieniz, S.; Wolf, L.; Lee, M.; Camargo, F. A. O.; Okeke, B. C., (2010). Characterization of copper bioreduction and biosorption by a highly copper resistant bacterium isolated from copper-contaminated vineyard soil. Sci. Total Environ., 408 (1), 1501-1507 (7 pages).

Babel, S.; Opiso, E. M., (2007). Removal of Cr from synthetic wastewater by sorption into volcanic ash soil. Int. J. Environ. Sci. Tech., 4 (1), 99-107 (10 pages).

Brierley, C. L., (1990). Bioremediation of metal-contaminated surface and groundwaters, Geomicrobiol. J., 8 (3-4), 201-223 (23 pages).

Burlage, R. S.; Bemis, L. A.; Layton, A. C.; Sayler, G. S.; Larimer, F., (1990). Comparative genetic organization of incompatibility group P degradative plasmids. J. Bacteriol., 172 (12), 68186825 (8 pages).

Calomoris, J. J.; Armstrong, T. L.; Seidler, R. J., (1984). Association of metal-tolerance with multiple antibiotic resistance of bacteria isolates from drinking water. Appl. Environ. Microbiol., 47 (6), 1238-1242 (5 pages).

Celaya, R. J.; Noriega, J. A.; Yeomans, J. H.; Ortega, L. J.; RuizManr'ýquez A., (2000). Biosorption of Zn(II) by Thiobacillus ferrooxidans. Bioproc. Eng., 22 (6), 539-542 (4 pages).

Chang, J. S.; Hong, J., (1994). Biosorption of mercury by the inactivated cells of Pseudomonas aeruginosa PU21. Biotechnol. Bioeng., 44 (8), 999-1006 (8 pages).

Chang, J. S.; Law, R.; Chang, C. C., (1997). Biosorption of lead, copper and cadmium by biomass of Pseudomonas aeruginosa PU21. Water Res., 31 (7), 1651-1658 (8 pages).

Chen, B. Y.; Utgikar, V. P.; Harmon, S. M.; Tabak, H. H.; Bishop, D. F.; Govind, R., (2000). Studies on biosorption of zinc(II) and copper(II) on Desulfovibrio desulfuricans. Int. Biodeterior. Biodegrad., 46 (1), 11-18 (8 pages).

Davis, J. A.; Volesky, B.; Vierra, R. H. S. F., (2000). Sargassum seaweed as biosorbent for heavy metals. Water Res., 34 (17), 4270-4278 (6 pages).

Fourest, E.; Roux, J. C., (1992). Heavy metal biosorption by fungal mycelia by-product mechanisms and influence of $\mathrm{pH}$. Appl. Microbiol, Biotech., 37 (13), 399-403 (5 pages).

Hall, T. A., (1999). BioEdit: A user-friendly biological sequence alignment editor and analysis program for Windows 95/98/ NT. Nucl. Acids. Symp. Ser., 41, 95-98 (4 pages).

Hamman, S., (2004). Bioremediation Capabilities of White Rot Fungi. No. BI570 - review article Spring.

Kahru, A.; Pollumaa, L.; Reiman, R.; Ratsep, A.; Liiders, M.; Maloveryan, A., (2000). The toxicity and biodegradability of eight main phenolic compounds characteristic to the oilshale industry wastewaters: A test battery approach. Environ. Toxicol. 15 (5), 431-442 (12 pages).

Kobya, M.; Demirbas, E.; Senturk, E.; Ince, M., (2005). Adsorption of heavy metal ions from aqueous solutions by activated carbon prepared from apricot stone. Bioresour. Tech., 96 (13), 1518-1521 (4 pages).

Kurek, E.; Czaban, J.; Bollag, J., (1982). Sorption of cadmium by microorganisms in competition with other soil constituents. Appl. Environ. Microbiol., 43 (5), 1011-1015 (5 pages).

Lane, D. J., (1991). 16S/23S rRNA Sequencing. in: Stuckebrandet, E.; Goodfellow, M., (Eds.) Nucleic acid techniques in bacterial systematic. John Wiley and Sons, New York, 115-148 (34 pages). Liu, Y.; Chang, X.; Guo, Y.; Meng, S., (2006). Biosorption and preconcentration of lead and cadmium on waste Chinese 
herb Pang Da Hai, J. Hazard. Mater., B135, 389-394 (6 pages).

Lodeiro, P.; Cordero, B.; Barriada, J. L.; Herrero, R.; Sastre de Vicente, M. E., (2005). Bosorption of cadmium by biomass of brown marine Macroalgae. Bioresour. Tech., 96 (1), 17961803 (8 pages).

Mahvi, A. H., (2008). Application of agricultural fibers in pollution removal from aqueous solution. Int. J. Environ. Sci. Tech., 5 (2), 275-285 (11 pages).

Malakootian, M.; Nouri, J.; Hossaini, H., (2009). Removal of heavy metals from paint industries wastewater using Leca as an available adsorbent. Int. J. Environ. Sci. Tech., 6 (2), 183190 (8 pages).

Nameni, M.; Alavi Moghadam, M. R.; Arami, M., (2008). Adsorption of hexavalent chromium from aqueous solutions by wheat bran. Int. J. Environ. Sci. Tech., 5 (2), 161-168 (8 pages).

Okafor, E. Ch., Opuene, K., (2007). Preliminary assessment of trace metals and polycyclic aromatic hydrocarbons in the sediments. Int. J. Environ. Sci. Tech., 4 (2), 233-240 (8 pages).

Okeke, B. C., (2008). Bioremoval of hexavalent chromium from water by a salt tolerant bacterium, Exiguobacterium sp. GS1. J. Ind. Microbiol. Biot., 35 (12), 1571-1579 (8 pages).

Okeke, B. C.; Laymon, J.; Crenshaw, S.; Oji, C., (2008). Environment and kinetic parameters for $\mathrm{Cr}$ (VI) bioreduction by a bacterial monoculture purified from $\mathrm{Cr}(\mathrm{VI})$-resistant consortium. Biol. Trace Elem. Res., 123 (1-3), 229-241 (13 pages).

Page, R. D., (1996). Treeview: An application to display phylogenetic trees on personal computers. Comput. Appl. Biosci., 12 (4), 357-358 (2 pages).

Panjeshahi, M. H.; Ataei, A., (2008). Application of an environmentally optimum cooling water system design in water and energy conservation. Int. J. Environ. Sci. Tech., 5 (2), 251-262 (12 pages).

Parungao, M. M.; Tacata, P. S.; Tanayan, G. C.; Trinidad, L. C., (2007). Biosorption of copper, cadmium and lead by copperresistant bacteria isolated from Mogpog River, Marinduque. Philip. J. Sci., 136 (2), 155-166 (12 pages).

Quershi, A. A.; Bulich, A. A.; Isenberg, D. L., (1998). Microtox toxicity test systems- where they stand today. In microscale testing in aquatic toxicology: Advances, techniques, and practice. in: Wells, P. G.; Lee, K.; Blaise, C. (Eds.), Воса Raton, Florida: CRC Press, 185-199.

Saitou, N.; Nei, M., (1987). The neighbour- joining method: A new method for reconstructing phylogenetic trees. Mol. Boil. Evol., 4 (4), 406-425 (20 pages).

Samarghandi, M. R.; Nouri, J.; Mesdaghinia, A. R.; Mahvi, A. H.; Nasseri, S.; Vaezi, F., (2007). Efficiency removal of phenol, lead and cadmium by means of $\mathrm{UV} / \mathrm{TiO}_{2} / \mathrm{H}_{2} \mathrm{O}_{2}$ processes. Int. J. Environ. Sci. Tech., 4 (1), 19-25 (7 pages).
Shakibaie, M. R.; Khosravan, A.; Frahmand, A.; Zare, S., (2008). Application of metal resistant bacteria by mutational enhancement technique for bioremediation of copper and zinc from industrial wastes. Iran. J. Environ. Health. Sci. Eng., 5 (4), 251-256 (6 pages)

Sharma, P.; Kumari, P.; Srivastava, M. M.; Srivastava, S., (2006). Removal of cadmium from aqueous system by shelled moringa oleifera lam. Seed powder. Bioresour. Tech., 97 (2), 299-305 (7 pages).

Silva, R. M. P.; Rodrigez, A. A.; De Oca, J. M. G. M.; Moreno, D. C., (2009). Biosorption of chromium, copper, manganese and zinc by Pseudomonas aeruginosa AT18 isolated from a site contaminated with petroleum. Bioresour. Tech., 100 (4), 1533-1538 (6 pages).

Sultan, S.; Hasnain, S., (2007). Reduction of toxic hexavalent chromium by Ochrobactrum intermedium strain SDCr-5 stimulated by heavy metals. Bioresour. Tech., 98 (2), 340344 (5 pages).

Tsezos, M., (1985). The selective extraction of metals from solutions by microorganisms. A brief overview. Can. Met. Q., 24 (2), 141-144 (4 pages).

Vasudevan, P.; Padmavathy, V.; Dhingra, S. C., (2003). Kinetics of biosorption of cadmium on Baker's yeast. Bioresour. Tech., 89 (3), 281-287 (7 pages).

Vinodhini, R.; Narayanan, M., (2008). Bioaccumulation of heavy metals in organs of fresh water fish Cyprinus carpio (Common carp). Int. J. Environ. Sci. Tech., 5 (2), 179-182 (4 pages).

Volesky, B., (1994). Advances in biosorption of metals: Selection of biomass types. FEMS Microbiol. Rev., 14 (4), 291-302 (12 pages).

Vullo, D. L.; Ceretti, H. M.; Marýáa Alejandra D.; Ramírez, S., A. M.; Zalts, A., (2008). Cadmium, zinc and copper biosorption mediated by Pseudomonas veronii $2^{\text {th }}$ Ed., Bioresour. Tech., 99 (13), 5574-5581 (8 pages).

WHO, (2010). Guideline for drinking water quality recommendations, (Vol. 1), World Health Organization, Geneva.

Yahaya, Y. A.; Don, M. M.; Bhatia, S., (2009). Biosorption of copper (II) onto immobilized cells of Pycnoporus sanguineus from aqueous solution: Equilibrium and kinetic studies. J. Hazard. Mater., 161 (1), 189-195 (7 pages).

Zaki, S.; Abd-El-Haleem, D.; Abulhamd, A.; Elbery, H.; AbuElreesh, G., (2008). Influence of phenolics on the sensitivity of free and immobilized bioluminescent Acinetobacter bacterium. Microbiol. Res., 163 (3), 277-285 (9 pages).

Zvinowanda, C. M.; Okonkwo, J. O.; Shabalala, P. N.; Agyei, N. M., (2009). A novel adsorbent for heavy metal remediation in aqueous environments. Int. J. Environ. Sci. Tech. 6 (3), 425-434 (10 pages).

\section{AUTHOR (S) BIOSKETCHES}

Farag, S., Ph.D., Researcher, Department of Environmental Biotechnology, Genetic Engineering and Biotechnology Research Institute, Mubarak City for Scientific Research and Technology Applications, Alexandria, Egypt. Email: sohafarag88@yahoo.com

Zaki , S., Ph.D., Department of Environmental Biotechnology, Genetic Engineering and Biotechnology Research Institute, Mubarak City for Scientific Research and Technology Applications, Alexandria, Egypt. Email: saharzaki@yahoo.com

How to cite this article: (Harvard style)

Farag, S.; Zaki, S., (2010). Isolation and molecular characterization of some copper biosorped strains. Int. J. Environ. Sci. Tech., 7 (3), 553-560. 